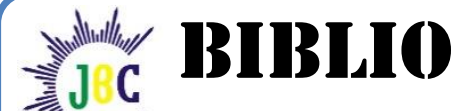 COUNS}

Biblio Couns : Jurnal Kajian Konseling dan Pendidikan

Vol. 2, No. 3, November 2019, hlm. 125-130 Tersedia Online di jurnal.umsu.ac.id/index.php/biblio

ISSN 2620-3103 (online)

DOI: https://doi.org/10.30596/bibliocouns.v2i3.3738

\title{
Analisis Motiviasi Berprestasi Siswa Serta Implikasinya dalam Pelayanan Bimbingan dan Konseling
}

\author{
Riska Andriani \\ Universitas Indraprasta PGRI Jakarta. Korespondensi: JI. Nangka No. 58 C (TB. Simatupang), \\ Jakarta Selatan, DKI. Jakarta, Indonesia. E-mail: riskaandriani366@gmail.com
}

\section{Article Info}

History of Article

Submited November 2019

Accepted November 2019

Published November 2019

\section{Key Word}

Achievement Motivation,

Students,

Guidance and Counseling

\section{Kata Kunci}

Motivasi Berprestasi,

Siswa,

Bimbingan dan Konseling.

\begin{abstract}
This research is motivated by the low achievement motivation of students. This study aims to describe the student achievement motivation. The research method used is descriptive quantitative. population in this study is numbered 105 people. The sample consisted of 105 students, the sampling technique used saturated samples. The research findings show that students' achievement motivation is in the high category.
\end{abstract}

\begin{abstract}
Abstrak
Penelitian ini dilatarbelakangi oleh rendahnya motivasi berprestasi siswa. penelitian ini bertujuan untuk mendeskripsikan motivasi berpretasi siswa. Metode penelitian yang digunakan adalah kuantitatif deskriptif. Populasi dalam penelitian ini berjumlah 105 orang. Sampel berjumlah 105 orang, teknik pengambilan sampel menggunakn sampel jenuh. Temuan penelitian menunjukkan bahwa motivasi berprestasi siswa berada pada kategori tinggi.
\end{abstract}

\section{Citation Info}

Andriani, R. (2019). Analisis motiviasi berprestasi siswa serta implikasinya dalam pelayanan bimbingan dan konseling. Biblio Couns: Jurnal Kajian Konseling dan Pendidikan. 2(3), 125130. 


\section{PENDAHULUAN}

Kegiatan Pembelajaran di sekolah dipengaruhi oleh banyak faktor. Salah satunya adalah motivasi berprestasi. Motivasi berprestasi sebagai motif yang mendorong individu untuk meraih sukses dan bertujuan untuk meraih hasil dengan standar tertentu (McClelland, 1987). Sedangkan, Davis \& Newstron mendefiniskan motivasi berprestasi sebagai dorongan yang dimiliki oleh seseorang untuk mengatasi hambatan dalam mencapai tujuan, sehingga individu yang memiliki motivasi berprestasi tinggi menunjukkan usaha yang lebih besar dan ulet (Davis \& Newstrom, 1989). Selanjutnya, sebagai daya penggerak motivasi berprestasi memiliki pengaruh dalam mewujudkan keberhasilan siswa untuk mencapai standar keunggulan dalam proses belajar (Oktasari, 2017). Hal tersebut bermakna bahwa motivasi berprestasi harus ada dalam diri siswa.

Lebih lanjut, Motivasi berprestasi yang ada dalam diri siswa akan menentukan keberhasilan siswa dalam belajar. Siswa yang memiliki motivasi berprestasi yang tinggi cenderung memiliki target kriteria atau standar yang telah ditetapkannya karena pada prinsipnya berkaitan dengan harapan untuk sukses dan kecenderungan untuk menghindari kegagalan. Sebaliknya, siswa yang mempunyai motivasi berprestasi yang rendah cenderung tidak memiliki target kriteria atau standar keunggulan yang ditetapkan. Dengan kata lain, jika siswa memiliki motivasi berprestasi yang tinggi, maka siswa cenderung beranggapan bahwa prestasi merupakan suatu hal yang harus diraih, diperjuangkan, dan dibanggakan. (Oktasari Maria, Solihatun, Monalisa, 2018).

Namun, faktanya hal tersebut bertentangan dengan beberapa hasil penelitian, antara lain: Penelitian Adiningtyas (2015) yang menunjukkan bahwa motivasi berprestasi siswa masih berada pada kategori rendah, baik untuk kelompok kontrol maupun kelompok eksperimen. Selanjutnya, temuan penelitian (Alit, 2003) yang menjelaskan motivasi berprestasi siswa berada dalam kategori cukup.

Kemudian, berdasarkan keterangan dari guru SMA Master Depok, didapatkan informasi bahwa ada beberapa indikasi yang ditunjukkan siswa yang diduga mempunyai motivasi berprestasi rendah, seperti: (1) beberapa siswa terlihat kurang serius dan kurang bersemangat dalam mengikuti pelajaran tertentu, (2) beberapa siswa memilih mengajak temennya bercerita, dibandingkan memperhatikan penjelasan dari guru (3) Siswa tidak membuat target nilai yang akan dicapai, (4) beberapa siswa hanya mengerjakan tugas yang mudah saja bahkan siswa cenderung akan mengabaikan tugasnya, (5) beberapa siswa masih mengerjakan pekerjaan rumah yang diberikan guru di sekolah.

Hal tersebut menjadi indikasi bahwa rendahnya motivasi berprestasi yang dimiliki oleh siswa, sehingga motivasi berprestasi siswa masih menjadi masalah nyata dalam kegiatan pembelajaran di sekolah, sehingga perlu dilakukan upaya untuk menyelesaikan permasalahan tersebut, Untuk itu penulis melakukan penelitian tentang motivasi berprestasi siswa SMA Master Depok. Penelitian bertujuan untuk melihat bagaimana gambaran motivasi berprestasi siswa di SMA Master Depok serta implikasinya dalam pelayanan bimbingan dan konseling. 


\section{METODE}

Penelitian ini menggunakan metode kuantitatif jenis deskriptif yang bertujuan untuk mendeskripsikan motivasi berprestasi siswa. Populasi penelitian ini mencakup seluruh siswa kelas X, XI dan XII SMA Master Depok yang terdaftar pada tahun ajaran 2017-2018 sebanyak 105 orang siswa. Penarikan sampel dalam penelitian ini dilakukan dengan menggunakan teknik sampling jenuh sehingga sampel berjumlah 105 orang. Instrumen yang digunakan skala motivasi berprestasi yang dibuat oleh Maria Oktasari. Data Analisis dengan statistik deskriptif.

\section{HASIL}

Untuk mengetahui bagaimana gambaran motivasi berprestasi siswa SMA Master Depok, maka penulis telah melakukan analisis deskriptif terhadap data penelitian. Adapun hasil yang telah didapatkan sebagai berikut:

Tabel 1 Distribusi Frekuensi Motivasi Berprestasi Berdasarkan Kategori ( $n=105)$.

\begin{tabular}{clcc}
\hline Interval Skor & \multicolumn{1}{c}{ Kategori } & Frekuensi & $\%$ \\
\hline $\mathbf{2} \mathbf{1 3 0}$ & Sangat Tinggi (ST) & 6 & 5.71 \\
\hline $\mathbf{1 0 5}-\mathbf{1 2 9}$ & Tinggi (T) & 59 & 56.19 \\
\hline $\mathbf{8 0 - 1 0 4}$ & Sedang (S) & 34 & 32.38 \\
\hline $\mathbf{5 5 - 7 9}$ & Rendah (R) & 6 & 5.71 \\
\hline $\mathbf{5 4}$ & Sangat Rendah (SR) & 0 & 0.00 \\
\hline & Total & $\mathbf{1 0 5}$ & $\mathbf{1 0 0}$
\end{tabular}

Berdasarkan tabel 1 di atas, hasil yang diperoleh memperlihatkan bahwa motivasi berprestasi siswa SMA Master Depok berada pada kategori tinggi. Namun demikian, masih terdapat variasi skor motivasi berpretasi siswa tersebut.

Selanjutnya, untuk melihat bagaimana gambaran motivasi berprestasi dari masing-masing indikator, dijelaskan pada tabel 2 di bawah ini:

Tabel 2 Rata-rata (Mean) dan Persentase (\%) Motivasi Berprestasi Siswa

Berdasarkan Indikator $(n=105)$

\begin{tabular}{|c|c|c|c|c|c|c|c|c|c|}
\hline \multirow{2}{*}{ Variabel } & \multirow{2}{*}{ Indikator } & \multicolumn{7}{|c|}{ Skor } & \multirow{2}{*}{ Ket. } \\
\hline & & Idela & Max & Min & $\sum$ & Mean & $\%$ & Sd. & \\
\hline \multirow[t]{4}{*}{$\begin{array}{l}\text { Motivasi } \\
\text { Berprestasi }\end{array}$} & $\begin{array}{l}\text { Memiliki Tanggung } \\
\text { Jawab Pribadi (6) }\end{array}$ & 30 & 29 & 14 & 2307 & 21,97 & 73,23 & 3,21 & $\mathrm{~T}$ \\
\hline & $\begin{array}{l}\text { Memilih tugas yang } \\
\text { Menantang ( } 7)\end{array}$ & 35 & 35 & 14 & 2552 & 24,30 & 69,42 & 4,01 & $\mathrm{~T}$ \\
\hline & $\begin{array}{l}\text { Memperhatikan } \\
\text { umpan } \\
\text { Balik (8) }\end{array}$ & 40 & 40 & 3 & 2998 & 28,55 & 71,37 & 4,97 & $\mathrm{~T}$ \\
\hline & $\begin{array}{l}\text { Berusaha keras } \\
\text { untuk } \\
\text { Mencapai standar } \\
\text { yang } \\
\text { Ditetapkan (10) }\end{array}$ & 50 & 47 & 22 & 3513 & 27,46 & 54,92 & 4,54 & $S$ \\
\hline \multicolumn{2}{|c|}{ Keseluruhan (31) } & 155 & 144 & 72 & 11370 & 108,29 & 69,67 & 12,74 & $\mathbf{T}$ \\
\hline
\end{tabular}


Berdasarkan Tabel 2 di atas, terlihat bahwa secara rata-rata keseluruhan motivasi berprestasi siswa berada pada kategori tinggi, dengan tingkat capaian sebesar 69.67\%. Namun, dari analisis indikator berusaha keras untuk mencapai standar yang ditetapkan masih berada pada kategori sedang yaitu 54.92\%..

\section{PEMBAHASAN}

Berdasarkan hasil analisis diketahui bahwa secara rata-rata keseluruhan motivasi berprestasi siswa berada dalam kategori tinggi dan pencapaian masingmasing indikator diketahui bahwa semua indikator berada pada kategori tinggi. Hasil ini memberikan makna bahwa siswa telah mempunyai motivasi berprestasi yang tinggi dalam proses pembelajaran. Hal tersebut merupakan suatu hal yang baik, karena dalam proses pembelajaran motivasi berprestasi merupakan sesuatu yang mutlak harus ada dalam diri siswa.

Sebagaimana pendapat para ahli bahwa motivasi berprestasi adalah keinginan untuk menyelesaikan sesuatu, untuk mencapai suatu standar kesuksesan, dan melakukan suatu usaha dengan tujuan untuk mencapai kesuksesan (Santrock, 2003). McClelland mengartikan motivasi berprestasi sebagai motif yang mendorong individu untuk meraih sukses dan bertujuan untuk meraih hasil dengan standar tertentu (McClelland, 1987). Sedangkan, Davis \& Newstron mendefiniskan motivasi berprestasi sebagai dorongan yang dimiliki oleh seseorang untuk mengatasi hambatan dalam mencapai tujuan, sehingga individu yang memiliki motivasi berprestasi tinggi menunjukkan usaha yang lebih besar dan ulet (Davis \& Newstrom, 1989).

Lebih lanjut, Dalam rangka belajar di sekolah, motivasi berprestasi terwujud dalam daya penggerak pada siswa untuk mengusahakan kemajuan dalam belajar dan mengejar taraf prestasi maksimal, demi pengayaan diri sendiri dan penghargaan terhadap diri sendiri (Winkel, 2007). Mc. Clelland, dkk motivasi berprestasi adalah keberhasilan individu dalam persaingan dengan beberapa standar keunggulan kesuksesan. Dalam persaingan individu mungkin saja gagal dalam mencapai tujuannya, namun dengan adanya persaingan ini masih memungkinkan seorang untuk lebih berusaha lagi mencapai prestasi yang diinginkan (Moore \& Rotter, 2010). Lebih lanjut, motivasi berprestasi merupakan keinginan untuk mencapai sesuatu yang sulit, mencapai standar keberhasilan yang tinggi, menguasai tugas-tugas kompleks, dan individu yang memiliki motivasi berprestasi berusaha untuk mencapai tujuan yang realistis tetapi menantang (Daft, 2008).

Penjelasan di atas dapat disimpulkan bahwa motivasi berprestasi merupakan daya penggerak yang menggerakkan individu untuk meraih standar kesuksesan dengan mengerahkan segala kekuatan, kemampuan dan keterampilan yang ada dalam dirinya,. Keberhasilan dalam mencapai standar keunggulan dapat digunakan oleh siswa untuk mengevaluasi kegiatan yang telah dilakukan.

Lebih lanjut, hasil penelitian yang didapatkan menunjukkan bahwa motivasi berprestasi siswa berada dalam kategori tinggi. Hasil tersebut menunjukkan suatu hal yang positif. Hal tersebut juga menjadi pertanda bahwa motivasi berprestasi siswa 
harus tetap dikembangkan dan ditingkatkan dalam diri siswa, sehingga mendorong siswa untuk lebih meningkatkan motivasi berprestasinya dan meraih keberhasilan dalam sesuai dengan standar yang ditetapkan.

Lebih lanjut, siswa yang telah berprestasi perlu diberikan umpan balik dari lingkungannya sebagai bentuk pengakuan terhadap prestasinya. Contoh: memberikan penghargaan atas hasil belajar yang siswa dapatkan, siswa akan merasa senang atas pengakuan berprestasi dari guru dan orangtuanya, sehingga hal ini akan menimbulkan motivasi dirinya untuk lebih giat belajar dan lebih baik dalam berprestasi. Siswa yang mendapatkan pengakuan berprestasi akan merasa bahwa dirinya dihargai serta akan merasa bangga atas keberhasilan yang telah dicapainya selama ini. Motivasi berprestasi seperti ini akan menimbulkan semangat lebih maju dalam bekerja, lebih memacu seseorang menimbulkan ide-ide cemerlang yang bagus bagi kemajuan dirinya. Apabila yang menjadi tujuannya itu telah tercapai, maka akan menimbulkan kepuasan pribadi atas kerja kerasnya tersebut.

Berdasarkan penjelasan di atas maka temuan penelitian yang didapatkan tersebut perlu ditindaklanjuti, sehingga penulis menyarankan kepada guru BK/Konselor untuk menggunakan data penelitian sebagai dasar untuk membuat program BK sehingga mampu mengembangkan dan meningkatkan motivasi berprestasi siswa dalam proses pembelajaran di sekolah. Guru BK atau konselor dapat memfokuskan penyusunan program pada bidang pengembangan belajar. Jika hal tersebut dilakukan secara berkesinambungan, maka siswa akan merasakan dampak nyata bagi peningkatan motivasi berprestasi yang dimiliki siswa.

\section{KESIMPULAN}

Berdasarkan temuan dan pembahasan hasil penelitian, dapat dikemukakan kesimpulan sebagai berikut: hasil analisis motivasi berprestasi siswa SMA Master Depok berada pada kategori tinggi. Kemudian, penelitian ini dilaksanakan dengan populasi siswa SMA Master Depok diduga memiliki karekteristik tertentu, yang mungkin berbeda dengan karakteristik siswa SMA lainnya. Oleh karena itu, peneliti selanjutnya diharapkan dapat menindaklanjuti penelitian ini dengan jumlah sampel yang lebih besar dan jangka waktu yang relatif lebih lama, pada beberapa sekolah yang memiliki kemungkinan mengalami masalah-masalah yang sama dengan penelitian ini.

\section{DAFTAR RUJUKAN}

Adiningtiyas, S. W. 2015. "Efektivitas Layanan Informasi dengan Media untuk Meningkatkan Motivasi Berprestasi Siswa”. Tesis tidak diterbitkan. Padang: Prodi S2 BK FIP UNP.

Alit, D. M. (2003). Kontribusi Faktor Lingkungan Sekolah, Lingkungan Keluarga, dan Motivasi Berprestasi terhadap Nilai Modern Siswa Sekolah Lanjutan Tingkat Pertama (SLTP) di Kabupaten Gianyar, Bali. Jurnal Penelitian Dan Evaluasi Pendidikan, 5(6). 
Daft, R. L. (2008). The leadership experience 4th ed. Thomson South-Western, 2021.

Davis, K., \& Newstrom, J. W. (1989). Human behavior at work: Organizational behavior.

McClelland, D. C. (1987). Human motivation. CUP Archive.

Moore, L. L., \& Rotter, C. (2010). Using Achievement Motivation Theory to Explain Student Participation in a Residential Leadership Learning Community, 9(2), 22-34.

Oktasari, M. (2017). Perceptions around teacher 's social support with student achievement motivation, 1(2), 145-150.

Oktasari Maria, Solihatun, Monalisa, M. (2018). Kontribusi Dukungan Sosial Teman Sebaya Terhadap Motivasi Berprestasi Siswa, 1(1), 22-28.

Santrock, J. W. (2003). Adolescence (Perkembangan Remaja), Alih Bahasa Shinto B. Adelar Dan Sherly Saragih, Jakarta: Erlangga.

Winkel, W. S. (2007). Psikologi pendidikan dan evaluasi belajar. Gramedia. 